\title{
Analysis of Risk Features and Performance Evaluation of Shariah-Compliance Stocks using Standard-Risk Adjusted Techniques
}

Farah Azaliney Mohd Amin, Md Nizam Udin, Maizatul Shazwani T.Tairuddin, Syarifah Mahani Bt Syed Syahrill, Aliya Bt Moh Halmi, Nur Amirah binti Mohd Jasni

To Link this Article: http://dx.doi.org/10.6007/IJARBSS/v11-i11/11243

DOI:10.6007/IJARBSS/v11-i11/11243

Received: 05 September 2021, Revised: 29 September 2021, Accepted: 21 October 2021

Published Online: 08 November 2021

In-Text Citation: (Amin et al., 2021)

To Cite this Article: Amin, F. A. M., Udin, M. N., T.Tairuddin, M. S., Syarifah Mahani Bt Syed Syahrill, A. B. M. H., \& Jasni, N. A. binti M. (2021). Analysis of Risk Features and Performance Evaluation of Shariah-Compliance Stocks using Standard-Risk Adjusted Techniques. International Journal of Academic Research in Business and Social Sciences, 11(11), $303-316$.

Copyright: @ 2021 The Author(s)

Published by Human Resource Management Academic Research Society (www.hrmars.com)

This article is published under the Creative Commons Attribution (CC BY 4.0) license. Anyone may reproduce, distribute, translate and create derivative works of this article (for both commercial and non-commercial purposes), subject to full attribution to the original publication and authors. The full terms of this license may be seen

at: http://creativecommons.org/licences/by/4.0/legalcode

Vol. 11, No. 11, 2021, Pg. $303-316$

Full Terms \& Conditions of access and use can be found at http://hrmars.com/index.php/pages/detail/publication-ethics 


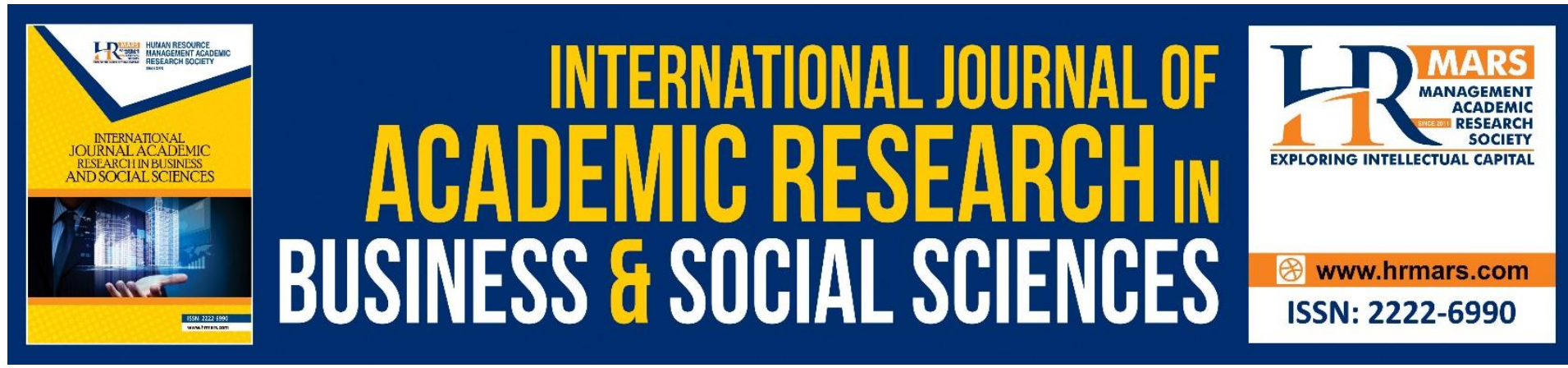

\title{
Analysis of Risk Features and Performance Evaluation of Shariah-Compliance Stocks using Standard-Risk Adjusted Techniques
}

\author{
Farah Azaliney Mohd Amin ${ }^{1}$, Md Nizam Udin², Maizatul \\ Shazwani T.Tairuddin ${ }^{3}$, Syarifah Mahani Bt Syed Syahrill ${ }^{4}$, \\ Aliya Bt Moh Halmi ${ }^{5}$, Nur Amirah binti Mohd Jasni ${ }^{6}$ \\ 1,2,3,4,5 Faculty of Computer and Mathematical Sciences, Universiti Teknologi MARA
} Cawangan Negeri Sembilan, Kampus Seremban, Malaysia, ${ }^{6}$ Fleet Management Department Petronas Dagangan Berhad (PDB) Level 29, Tower 1, Petronas Twin Tower KLCC 50088 KLCC, Kuala Lumpur

Email: farah525@uitm.edu.my

\begin{abstract}
The Islamic Capital Market (ICM) has grown rapidly in line with the increasing demand for various Shariah-compliant investment instruments. As the fastest growing investment component, Shariah-compliant stocks in Bursa Malaysia have attracted more attention not only to Muslim investors but also to non-Muslims investors to meet their investment objectives. However, most of the literature focused on the performance comparisons of Islamic and conventional indices. This study contributes to examine the overall performance of Shariah-compliant stocks across sectors which has significant implications into the relationship of risk-return. Therefore, the main objective of this study is to analyse the risk features of 57 Shariah-compliant stocks from 12 sectors from 2013 to 2018. Next, this study also focuses on evaluating the performance of Shariah-compliant at the sector level by using the standard-risk adjusted performance methods towards $\mathrm{KLCl}$. Methods employed were Sharpe, Treynor and Jensen's Alpha ratios. The empirical results reveal that the unsystematic risk component in Shariah-compliant stocks is very high with an average diversifiability measure of 0.914 . The results indicate that all Shariah-compliant stocks are not fully diversified and there are still great opportunities for diversification. While the results show that the Islamic sectors have slightly outperformed the $\mathrm{KLCl}$, it also highlights that application of different risk variables used such as standard deviation and beta will lead to differences in the performance ranking. At best, investors could use this ranking to make investment decisions without undertaking time-consuming analysis to determine the highest and lowest performing sectors in the stock market.
\end{abstract}

Keywords: Islamic Stock, Systematic Risk, Unsystematic Risk, Performance Measurement 


\section{Introduction}

In recent years, there is a sharp increase in the demand for Islamic financial products and services in an emerging market, especially in Malaysia. Statistically, the local Islamic Capital Market (ICM) has grown dramatically from RM2.76 trillion in 2014 to RM2.9 trillion in 2020 (Sahudin et al., 2019). Previously, Muslim investors were unable to participate freely in the capital market due to financial instruments such as bonds, options, futures, forwards and swaps that function based on riba' (interest), gharar (uncertainty) or maisir (speculation) (Abdul-Rahim et al., 2019). Thus, Muslim investors are only willing to invest their capital if the investment does not conflict with Islamic laws as outlined by Al Quran and Sunnah.

As one of the world's leading Muslim countries, Malaysia has played an important role in promoting a variety of Islamic investments to its Muslim investors. Responding to this requirement, the Malaysian government has taken the initiative to establish the Islamic Banking Act 1983 and the Government Investment Act 1983 as a commitment to boost the local ICM. In May 1997, Bank Negara Malaysia authorised Shariah Advisory Council (SAC) to periodically monitor and ensure continuous conformity of the Shariah-compliant companies in conducting their operations and portfolios (Johan, 2018). Thus, a business that engages in risk and returns sharing activities as practised by conventional banking or investing in any non-compliance industries related to pork, alcoholic beverages, tobacco, pornography and entertainment has also been excluded from the Shariah-compliant securities list, published twice a year by the SAC.

About 700 stocks have been listed in Shariah-compliant Securities Commission Malaysia (SCM). The increasing demand for Islamic investment indicates that more investors have realised that Shariah-compliant stocks are less risky than conventional stocks. However, the investors are having a problem in making a decision on which stock market and sector they should invest in. Good investors will choose to maximise the possible return and minimising the level of risk. Generally, all types of investment instruments including Islamic equities that consist of two types of risk, namely systematic and unsystematic. Systematic risk is uncontrollable because it naturally affects the global economic market regardless of any asset due to inflation, interest rate changes, natural disasters, terrorist attacks, etc. (Jawadi et al., 2014). Meanwhile, unsystematic risk, on the other hand, is controllable since it is only associated with internal factors related to the performance of a specific company or an industry.

Therefore, this study has two objectives. The main objective is to analyse the risk features of local Shariah-compliant stocks by separating the total risk into systematic and unsystematic components. Next, this study also aims to identify the best performing Shariahcompliant stocks, both at the market level and by sector. Thus, this study utilises the most popular standard risk-adjusted techniques such as Sharpe, Treynor and Jensen's Alpha ratio as evaluation tools towards Kuala Lumpur Stock Exchange $(\mathrm{KLCl})$ as the market benchmark. As a result, a more efficient decision-making strategy in constructing an optimal portfolio can be applied by considering the risk-return perspective in the overall performance of Shariahcompliant stocks in Malaysia.

The remainder of this paper is organised as follows: Section 2 review the works of literature related to this study. Section 3 describes the methodology and data used in this 
paper. Section 4 discusses the empirical analysis. Section 5 summarises the findings and concludes the paper.

\section{Literature Review}

This section presents two types of empirical literature. In the first one, we aim to discuss the risk characteristics of Shariah-compliant stocks. In the second one, we emphasize the literature on the performance of Islamic stock market indices from the perspective of emerging countries, especially Malaysia.

Risk and return are significantly two important elements that have always been considered in their investment decisions whereby the higher the risk, the higher the return and vice versa (Amin et al., 2018). Even though Islamic stocks have grown in popularity, there have been few empirical studies analysing their overall risk-return characteristics. Recently, Abu-Alkheil et al (2020) have proved that Islamic stocks face a lower risk as compared to conventional stocks. Hence, Shariah-compliant stocks are claimed to be safer investment instruments than its counterpart (Mansor \& Bhatti, 2011). The empirical findings also found that the lower betas of Islamic indices can be explained by their lower leverage and less exposure to the credit market (Dewandaru et al., 2015; Mwamba et al., 2017; Rizvi \& Arshad, 2017).

As a result, the prices of Islamic equities become less sensitive to overall market movement that leads to Islamic portfolios in which it provides slightly less returns than the conventional portfolio (Rakhi et al., 2018; Sukmana \& Kholid, 2012). Since conventional stocks are more attractive in the market, investors prefer to strategically allocate less weight to Islamic stocks for long-term investment. This finding contradicts the results of a study conducted by Albaity and Ahmad (2008); Hayat and Kraeussl (2011); Charles et al (2015) which proved that Islamic stocks are riskier than their counterparts. Moreover, Abdullah et al (2002) have also found evidence that both Islamic and conventional funds were poorly diversified as their asset managers were bad at stock-picking and timing the market. Even though Islamic stocks lack diversification benefits, Hersugondo et al (2020); Kabir et al (2017); Tas et al (2016) have indicated that Islamic assets efficiently reduce systemic risk and make higher return relative to the conventional equity markets. These stocks could be more profitable since Shariah-compliance companies consist of small-cap companies with high rates of growth and have passed the extra-financial screening criterion (Hussein, 2004).

To the best of our knowledge, most of the prior studies focused on comparing the performance of Islamic and conventional indices in terms of equity investment at the stock market level (Siddiqui, 2000; Ho et al., 2014). It can also be observed that the empirical results over whether Islamic stocks perform better than non-Islamic stocks offer varied conclusions. Several studies have claimed that Shariah indices were slightly over-performed their conventional indices when markets were bearish and conventional funds outperformed its counterpart in bullish markets (Elfakhani et al., 2005). Thus, Islamic assets have been proven to be more resilient especially during the financial crisis. Therefore, it could be used as a hedging instrument making it more appealing to investors (Charles et al., 2015; Sukmana \& Kolid, 2012). 
In contradictory, Bouoiyour et al (2018); Ali et al (2018) concluded that Islamic indexes in emerging markets are relatively less efficient relative to non-Islamic indexes. This is consistent with Albaity and Ahmad (2008) findings in the local ICM that the KLSI minimally underperform the $\mathrm{KLCl}$ during the observed period. However, some literature did not find a significant difference between Islamic and conventional indices (Girard \& Hassan, 2008). In Malaysia, the findings from a study conducted by Ahmad and Ibrahim (2002) also revealed similar results between two indices particularly $\mathrm{KLSI}$ and $\mathrm{KLCl}$ traded in the Kuala Lumpur Stock Exchange (KLSE). Generally, previous studies suggest that investing in Islamic securities has no substantial impact on an investor's wealth as compared to non-Islamic assets (Abbes \& Trichilli, 2015; Dharani \& Natarajan, 2011). However, at the sectoral level, the performance of Islamic and conventional indices has received little attention. Therefore, this study will contribute to widening the existing Islamic literature by examining the current performance of Malaysian Shariah-compliant stocks at the sectoral level.

\section{Methodology}

This study aims to analyse risk features using beta, diversifiability measures and finally evaluate the performance of Shariah-compliant stocks using the standard risk-adjusted methods, namely Sharpe, Treynor and Jensen's alpha ratios. In addition, the sample of this study comprises 12 sectors with 57 approved Shariah-compliant securities listed by the Shariah Advisory Council (SAC) considered for a period of 6 years from 2013 to 2018. Finally, the 3-month Malaysia T-bill rate was employed to proxy for the risk-free rate and the weekly returns of the FTSE Bursa Malaysia Kuala Lumpur Composite Index (FBM KLCI) that serve as a proxy for market return. Figure 1 summarises the steps used to estimate the risk components and measure the performance of Shariah-compliant stock market portfolio towards KLCl: 


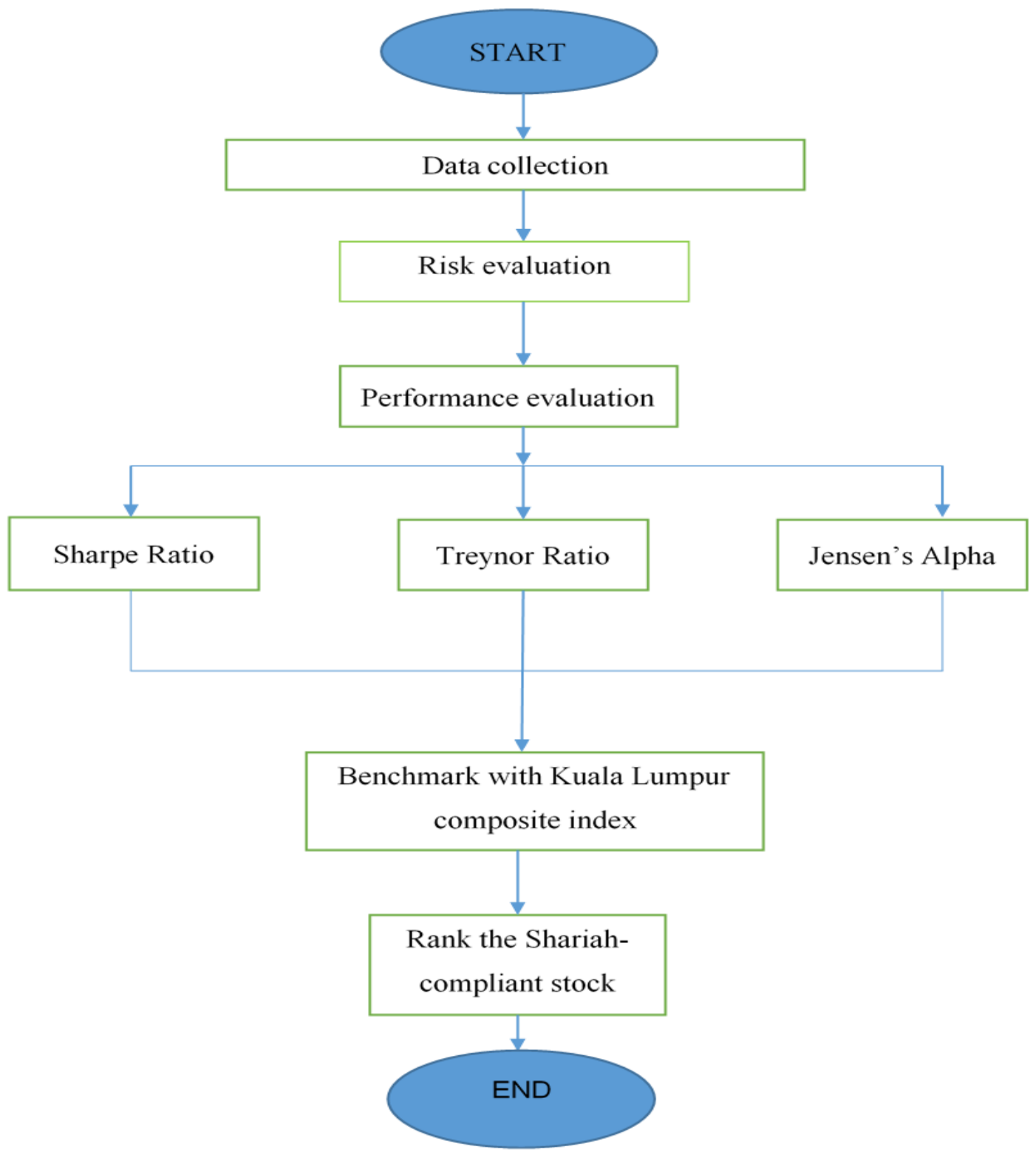

Figure 1: Flowchart of the risk and performance evaluation

\section{Analysis of Risk Features}

Beta

In the first part of the analysis, beta $(\beta)$ was employed as a risk measure to compare the stock's price movements relative to the entire market as a guidance on the future stock's performance. As shown in Equation (1), beta is the slope coefficient in the regression of the Shariah-compliant stock market portfolio rate of return on the market rate of return defined as

$$
\beta=\frac{\operatorname{cov}\left(R_{p}, R_{m}\right)}{\operatorname{var}\left(R_{m}\right)}
$$


where $R_{p}$ is the rate of return for stock $j, R_{m}$ is the rate of return of $\mathrm{KLCl}, \operatorname{cov}\left(R_{p}, R_{m}\right)$ is the covariance between the stock's return and the return of the market portfolio and $\operatorname{var}\left(R_{m}\right)$ represents the variance of $\mathrm{KLCl}$.

\section{Diversifiability Measure}

The variance of the total risk for each Shariah-compliant company is decomposed into its systematic and unsystematic risk components based on the following Equation (2) as shown in Wah and Johari (2014):

$$
\sigma_{j}^{2}=\beta_{j}^{2} \cdot \sigma_{m}^{2}+\sigma_{e}^{2}
$$

where $\sigma_{j}^{2}$ is the variance of stock return $j, \beta_{j}$ is the beta for stock $j, \sigma_{m}^{2}$ is the variance of the return of the market portfolio. Thus, $\beta_{j}^{2} \cdot \sigma_{m}^{2}$ is to represent the systematic risk component that is not diversifiable.

On the contrary, $\sigma_{e}^{2}$ defined the unsystematic risk component for stock $j$ which describes the portion of overall risk that is diversifiable. Additionally, this study also employs a measure of diversifiability $\left(\sigma_{e}^{2} / \sigma_{j}^{2}\right)$ to determine whether or not additional diversification is needed by estimating the ratio between unsystematic risk and the overall risk. In conclusion, if the ratio is close to 0 , this indicates that the portfolio is almost fully diversified since only a small portion of unsystematic risk components are available. However, if a portfolio's diversifiability measure is close to 1 , this implies that the portfolio still has a large portion of unsystematic risk that can further be diversified.

\section{Performance Analysis}

This study employed the standard risk-adjusted measure which was proposed by Sharpe (1966); Treynor (1965); Jensen (1968). In measuring the performance of Shariah-compliant stocks, the observed stocks are then benchmarked towards Kuala Lumpur Composite Index $(\mathrm{KLCl}) . \mathrm{KLCl}$ represents the average price of 100 stocks comprising both Islamic and nonIslamic compliant stocks and was acknowledged globally as one of the best references for Asia-Pacific equity.

First, the Sharpe ratio of each Shariah-compliant stock is the average of the excess return of a portfolio divided by its standard deviation of return is defined as follows:

$$
S=\frac{R_{i}-R_{f}}{\sigma_{i}}
$$

where $R_{i}$ and $\sigma_{i}$ are the average rate of return and standard deviation of return respectively, while $R_{f}$ is the average of the risk-free rate of return. In contrast to Sharpe, the Treynor ratio 
calculated the average total return of each Islamic stock divided by its beta, $\beta$ as shown below:

$$
T=\frac{R_{i}-R_{f}}{\beta}
$$

The final ratio employed in this study introduced by Jensen (1968) using the intercept alpha, $\alpha_{i}$, to evaluate the performance in the Capital Asset Pricing Model (CAPM) Lastly, the following equation is employed to calculate Jensen's Alpha:

$$
\alpha=R_{i}-\left[R_{f}+\beta\left(R_{m}-R_{f}\right)\right]
$$

where $R_{m}$ the average return of $\mathrm{KLCl}$.

\section{Results and Discussions}

Table 1 below reports the risk characteristics of each Shariah-compliant stock measured by using various measures such as beta, total risk (sum of systematic and unsystematic risk) and the diversifiability measure to further analyse the proportion of unsystematic components relative to the total risk.

Table 1: Risk features of Shariah-compliant stocks

\begin{tabular}{llllll}
\hline & $\begin{array}{l}\text { Beta } \\
\text { Shariah-compliant stocks }\end{array}$ & $\begin{array}{l}\text { Total } \\
\text { risk }\end{array}$ & $\begin{array}{l}\text { Systematic } \\
\text { risk } \\
\left(\sigma_{j}^{2}\right)\end{array}$ & $\begin{array}{l}\text { Unsystematic } \\
\left(\beta_{j}^{2} \sigma_{m}^{2}\right)\end{array}$ & $\begin{array}{l}\text { Diversifiability } \\
\left(\sigma_{e}^{2}\right)\end{array}$ \\
$\begin{array}{lllll}\text { measure } \\
\text { CONSUMER PRODUCTS \& SERVICES }\end{array}$ & & & & & \\
Acoustech Bhd & 0.447 & 8.518 & 0.708 & 7.810 & 0.917 \\
Advance Synergy Bhd & 0.041 & 9.282 & 0.485 & 8.797 & 0.948 \\
Amway (Malaysia) Holdings Bhd & 0.672 & 1.663 & 0.571 & 1.092 & 0.657 \\
Apollo Food Holdings Bhd & 0.589 & 3.845 & 0.033 & 3.812 & 0.991 \\
Ajinomoto (Malaysia) Bhd & 0.009 & 7.348 & 0.567 & 6.781 & 0.923 \\
\hline Average & 0.352 & 6.131 & 0.473 & 5.658 & 0.887 \\
\hline INDUSTRIAL PRODUCTS \& SERVICES & & & & & \\
\hline Ablegroup Bhd & 0.256 & 3.787 & 0.651 & 3.136 & 0.828 \\
Borneo Oil Bhd & 0.600 & 6.690 & 0.193 & 6.497 & 0.971 \\
Ajiya Bhd & 0.668 & 1.757 & 0.217 & 1.540 & 0.876 \\
Alcom Group Bhd & 0.331 & 5.157 & 1.763 & 3.394 & 0.658 \\
Amalgamated Industrial Steel Bhd & 0.217 & 5.236 & 0.404 & 4.832 & 0.923 \\
\hline Average & 0.414 & 4.525 & 0.646 & 3.880 & 0.851 \\
\hline ENERGY & & & & & \\
\hline Alam Maritim Resources Bhd & 0.872 & 4.85 & 0.216 & 4.634 & 0.955 \\
Dayang Enterprise Holdings Bhd & 0.905 & 4.906 & 0.339 & 4.567 & 0.931 \\
Dialog Group Bhd & 0.630 & 5.714 & 0.825 & 4.889 & 0.856 \\
Handal Resources Bhd & 0.152 & 8.715 & 0.213 & 8.502 & 0.976 \\
\hline
\end{tabular}


INTERNATIONAL JOURNAL OF ACADEMIC RESEARCH IN BUSINESS AND SOCIAL SCIENCES Vol. 11, No. 11, 2021, E-ISSN: 2222-6990 @ 2021 HRMARS

\begin{tabular}{|c|c|c|c|c|c|}
\hline Hengyuan Refining Company Bhd & 0.609 & 3.033 & 0.037 & 2.996 & 0.988 \\
\hline Average & 0.634 & 5.444 & 0.326 & 5.118 & 0.941 \\
\hline \multicolumn{6}{|l|}{ CONSTRUCTION } \\
\hline Ahmad Zaki Resources Bhd & 0.014 & 7.691 & 0.221 & 7.470 & 0.971 \\
\hline Ekovest Bhd & 0.608 & 7.107 & 0.929 & 6.178 & 0.869 \\
\hline Brem Holding Bhd & 0.874 & 8.757 & 0.565 & 8.192 & 0.935 \\
\hline Crest Builder Holdings Bhd & 0.555 & 8.607 & 0.395 & 8.212 & 0.954 \\
\hline DKLS Industries Bhd & 0.045 & 7.042 & 0.897 & 6.145 & 0.873 \\
\hline Average & 0.419 & 7.841 & 0.601 & 7.239 & 0.921 \\
\hline \multicolumn{6}{|l|}{ TRANSPORTATION \& LOGISTIC } \\
\hline Freight Management Holdings Bhd & 0.612 & 3.543 & 0.228 & 3.315 & 0.936 \\
\hline Boustead Heavy Industries Corp. Bhd & 0.531 & 4.057 & 0.151 & 3.906 & 0.963 \\
\hline Chin Hin Group Property Bhd & 0.136 & 4.251 & 0.038 & 4.213 & 0.991 \\
\hline CJ Century Logistics Holdings Bhd & 0.817 & 8.304 & 0.306 & 7.998 & 0.963 \\
\hline Complete Logistic Services Bhd & 0.420 & 9.224 & 0.556 & 8.668 & 0.940 \\
\hline Average & 0.503 & 5.876 & 0.256 & 5.620 & 0.958 \\
\hline \multicolumn{6}{|l|}{ PROPERTY } \\
\hline Acme Holdings Bhd & 0.793 & 3.687 & 0.832 & 2.855 & 0.774 \\
\hline Amcorp Properties Bhd & 0.256 & 6.850 & 0.169 & 6.681 & 0.975 \\
\hline Amverton Bhd & 0.927 & 2.500 & 0.513 & 1.987 & 0.795 \\
\hline ARK Resources Holdings Bhd & 0.693 & 5.612 & 0.559 & 5.053 & 0.900 \\
\hline Asian Pac Holdings Bhd & 0.697 & 3.051 & 0.170 & 2.881 & 0.944 \\
\hline Average & 0.673 & 4.340 & 0.449 & 3.891 & 0.878 \\
\hline \multicolumn{6}{|l|}{ PLANTATION } \\
\hline Astral Asia Bhd & 0.204 & 8.999 & 0.211 & 8.788 & 0.977 \\
\hline Batu Kawan Bhd & 0.471 & 6.304 & 0.129 & 6.175 & 0.980 \\
\hline BLD Plantation Bhd & 0.068 & 5.708 & 0.024 & 5.684 & 0.996 \\
\hline Dutaland Bhd & 0.639 & 6.839 & 0.659 & 6.180 & 0.904 \\
\hline Cepatwawasan Group Bhd & 0.848 & 9.752 & 0.657 & 9.095 & 0.933 \\
\hline Average & 0.446 & 7.520 & 0.336 & 7.184 & 0.958 \\
\hline \multicolumn{6}{|l|}{ TECHNOLOGY } \\
\hline Censof Holdings Bhd & 0.031 & 9.784 & 0.944 & 8.840 & 0.904 \\
\hline Industronics Bhd & 0.999 & 8.206 & 0.019 & 8.187 & 0.998 \\
\hline D\&O Green Technologies Bhd & 0.738 & 2.681 & 0.269 & 2.412 & 0.900 \\
\hline Dagang Nexchange Bhd & 0.055 & 8.251 & 0.641 & 7.610 & 0.922 \\
\hline Dataprep Holdings Bhd & 0.877 & 8.710 & 0.480 & 8.230 & 0.945 \\
\hline Average & 0.540 & 7.526 & 0.471 & 7.056 & 0.934 \\
\hline \multicolumn{6}{|l|}{ UTILITIES } \\
\hline Gas Malaysia Bhd & 0.373 & 2.868 & 0.404 & 2.464 & 0.859 \\
\hline Taliworks Corporation Bhd & 0.939 & 9.119 & 0.078 & 9.041 & 0.991 \\
\hline Salcon Engineering Bhd & 0.556 & 8.735 & 0.376 & 8.359 & 0.957 \\
\hline PBA Holdings Bhd & 0.081 & 4.523 & 0.016 & 4.507 & 0.996 \\
\hline Petronas Gas Bhd & 0.555 & 5.053 & 0.911 & 4.142 & 0.820 \\
\hline Average & 0.501 & 6.060 & 0.357 & 5.703 & 0.925 \\
\hline \multicolumn{6}{|l|}{ FINANCIAL SERVICES } \\
\hline BIMB Holdings Bhd & 0.601 & 3.043 & 0.835 & 2.208 & 0.726 \\
\hline
\end{tabular}


INTERNATIONAL JOURNAL OF ACADEMIC RESEARCH IN BUSINESS AND SOCIAL SCIENCES Vol. 11, No. 11, 2021, E-ISSN: 2222-6990 @ 2021 HRMARS

\begin{tabular}{llllll}
\hline Bursa Malaysia Bhd & 0.688 & 1.593 & 0.406 & 1.187 & 0.745 \\
\hline Average & 0.645 & 2.318 & 0.621 & 1.698 & 0.735 \\
\hline HEALTHCARE & & & & & \\
\hline Adventa Bhd & 0.269 & 8.707 & 0.191 & 8.516 & 0.978 \\
Apex Healthcare Bhd & 0.400 & 3.897 & 0.816 & 3.081 & 0.791 \\
Duopharma Biotech Bhd & 0.895 & 5.425 & 0.076 & 5.349 & 0.986 \\
Hartalega Holdings Bhd & 0.493 & 6.158 & 0.234 & 5.924 & 0.962 \\
KPJ Healthcare Bhd & 0.166 & 5.886 & 0.139 & 5.747 & 0.976 \\
\hline Average & 0.445 & 6.015 & 0.291 & 5.723 & 0.939 \\
\hline TELECOMMUNICATION \& MEDIA & & & & & \\
\hline Asia Media Group Bhd & 0.812 & 7.140 & 0.358 & 6.782 & 0.950 \\
Axiata Group Bhd & 0.318 & 9.580 & 0.946 & 8.634 & 0.901 \\
Digi.Com Bhd & 0.974 & 8.511 & 0.374 & 8.137 & 0.956 \\
Maxis Bhd & 0.012 & 6.862 & 0.441 & 6.421 & 0.936 \\
Pelangi Publishing Group Bhd & 0.089 & 10.064 & 0.473 & 9.591 & 0.953 \\
\hline Average & 0.441 & 8.431 & 0.518 & 7.913 & 0.939 \\
\hline
\end{tabular}

From the observation, the Property sector indicates to be the highest average beta, followed by the Financial Services and finally, the Energy sector with $0.673,0.645$ and 0.634 respectively. On the other hand, three Shariah-compliant sectors have the lowest beta namely Consumer, Industrial and Construction reported at 0.352, 0.414 and 0.419 respectively. The initial findings conclude that Islamic stocks are less sensitive and volatile towards changing in the market conditions since the estimated beta for all sectoral was generally very low (less than 1). Thus, the finding also provides evidence that these Islamic stocks possess relatively low systematic risks due to their risk-sharing strategy and the prohibition of debt financing nature.

As estimated by the diversifiability measure, the total risk of Shariah-compliant stocks due to the unsystematic risk component is very high, approximately $91 \%$. This poorly diversified condition may be due to the screening procedure implemented beforehand which finally limited the number of securities available in the local Shariah equities market. In the second part, this study further applied the three most popular standard risk-adjusted measures to evaluate the performance of Shariah-compliant stock across sectors. Table 2 below tabulates the ranking for 12 Shariah-compliant sectors in Malaysia. The chosen benchmark index is the $\mathrm{KLCl}$. 
INTERNATIONAL JOURNAL OF ACADEMIC RESEARCH IN BUSINESS AND SOCIAL SCIENCES

Vol. 11, No. 11, 2021, E-ISSN: 2222-6990 ๑ 2021 HRMARS

Table 2: Rankings of Shariah-compliant sectors using standard risk-adjusted methods

\begin{tabular}{lllllll}
\hline Shariah-compliant sector & Sharpe & Rank & Treynor & Rank & $\begin{array}{l}\text { Jensen's } \\
\text { Alpha }\end{array}$ & Rank \\
\hline Consumer Products \& Services & 0.041 & 13 & 0.033 & 13 & -0.244 & 12 \\
Industrial Products \& Services & 0.163 & 11 & 0.373 & 12 & -0.175 & 11 \\
Financial Services & 0.392 & 2 & 1.487 & 2 & 1.549 & 2 \\
Construction & 0.187 & 10 & 0.493 & 11 & -0.117 & 10 \\
Transportation \& Logistic & 0.347 & 4 & 1.082 & 4 & 0.907 & 4 \\
Property & 0.419 & 1 & 1.801 & 1 & 1.848 & 1 \\
Plantation & 0.246 & 7 & 0.699 & 9 & 0.387 & 9 \\
Energy & 0.376 & 3 & 1.235 & 3 & 0.957 & 3 \\
Utilities & 0.301 & 6 & 0.877 & 5 & 0.608 & 7 \\
Technology & 0.242 & 8 & 0.829 & 6 & 0.881 & 5 \\
Healthcare & 0.226 & 9 & 0.824 & 7 & 0.694 & 6 \\
Telecommunication \& Media & 0.319 & 5 & 0.714 & 8 & 0.488 & 8 \\
\hline KLCl & $\mathbf{0 . 1 3 6}$ & $\mathbf{1 2}$ & $\mathbf{0 . 5 5 4}$ & $\mathbf{1 0}$ & & \\
\hline \hline
\end{tabular}

As summarised in Table 2, a higher value of the measured ratio indicates a better performance of a sector that can be considered worthy to be invested in and vice versa. Surprisingly, the results show consistent ranking for the top four best performing sectors suggesting Property in the first place, followed by Financial Services, Energy and finally, Transportation and Logistics. Observed also, the following sectors such as Construction, Industrial and Consumer are considered inferior due to the lowest-ranked as a benchmark towards $\mathrm{KLCl}$.

Based on the Sharpe ratio, 92\% of the Shariah-compliant sectors observed outperformed the KLCl. Meanwhile, Treynor and Jensen's Alpha indicated that only $75 \%$ of sectors outperformed $\mathrm{KLCl}$. Overall, the empirical evidence showed that the Shariahcompliant sector slightly outperformed the $\mathrm{KLCl}$ since the average is approximately $81 \%$. Although the ranking for the other sectors is slightly different by using different measures, it can be concluded that the ranking produced by Jensen and Treynor is much more similar as compared to Sharpe. The possible reason for this is because Sharpe uses standard deviation as a risk variable, while beta is employed for the other two measures mentioned previously.

\section{Conclusion}

This study has successfully analysed the risk features and performance of 57 Shariahcompliant stocks across 12 sectors in Malaysia. Due to their lower betas, the initial findings indicate that the relative sensitivity of local Islamic stock returns is proven to be less affected by the overall performance of $\mathrm{KLCl}$. Thus, each Shariah-compliant stock can also be considered a less volatile asset because of its lower variances. Therefore, local Islamic stocks are suitable instruments especially for hedging purposes since the future prices of Shariahcompliant stocks are expected to be more steady. Despite their low risk, Lean and Parsva (2012) claimed that Islamic securities still perform very well which is appealing to Muslim investors. The empirical result also indicates that about $91 \%$ of the total risk came from the unsystematic risk component showing that there are still great diversification opportunities. Hence, this study is in line with Dewandaru et al (2015) suggesting that Islamic investors 
should focus more on sector diversification rather than country diversification in the shortterm investment.

Next, this study further examined the performance of the Malaysian Islamic stock market at the sectoral level employing three standard risk-adjusted methods: Sharpe, Treynor and Jensen Alpha. The results showed that the Islamic stock market performed slightly better than the market index, $\mathrm{KLCl}$. However, it is worth mentioning that the application of different risk variables leads to a difference in the performance ranking. Observed that, only systematic risk is used in Treynor and Jensen's Alpha, meanwhile Sharpe ratio takes into consideration both systematic and unsystematic risk components. Thus, it is not surprising that the empirical results of Treynor and Jensen's Alpha behave similarly as compared to the Sharpe. In addition, the performance using the standard risk-adjusted also shows consistent results to the previous beta estimates. The Property sector is ranked the best, while the Consumer sector is ranked the worst were found to be consistent with the highest and smallest beta respectively. Finally, the results of this investigation indicate that there is a significant relationship between beta and performance whereby higher beta will indicate higher expected returns that eventually lead to higher performance of stocks and vice versa.

The findings from this study provide important information especially to the risk-averse investors, regulators or market players who seek the best performing Shariah-compliant stocks from the whole basket of ICM. Moreover, this study also provides vital information that can be used in the asset allocation strategy by the portfolio managers to reduce unsystematic risk in constructing an optimal portfolio. Islamic stocks may be an alternative for conventional investors who want to diversify their portfolios with a less risky asset. Nonetheless, this study only focuses on beta, diversifiability measures and performance in the normal market condition. Hence, further study is encouraged to analyse other elements, including macroeconomic and fundamental factors, especially during the financial crisis. A possible extension of the current studies is to employ another performance measurement such as Modigliani Measure that expresses a stock performance relative to the market in percentage terms. This could be a benefit to the investor since the information on the performance is based on a particular market trend.

\section{References}

Abbes, M. B., \& Trichilli, Y. (2015). Islamic stock markets and potential diversification benefits. Borsa Istanbul Review, 15(2), 93-105.

Abdullah, F., Mohamed, S., \& Hassan, T. (2002). A Comparative performance of Malaysian Islamic and Conventional mutual funds. Pertanika, 8(2), 30-49.

Abdul-Rahim, R., Abdul-Rahman, A., \& Ling, P. S. (2019). Performance of shariah versus conventional funds: Lessons from emerging markets. Journal of Nusantara Studies (JONUS), 4(2), 193-218.

Abu-Alkheil, A., Khan, W. A., \& Parikh, B. (2020). Risk-reward trade-off and volatility performance of islamic versus conventional stock indices: Global evidence. Review of Pacific Basin Financial Markets and Policies, 23(01), 2050002.

Ahmad, Z., \& Ibrahim, H. (2002). A study of performance of the KLSE Syariah index. Malaysian Management Journal, 6(1\&2), 25-34. 
Albaity, M., \& Ahmad, R. (2008). Performance of Syariah and composite indices: Evidence from Bursa Malaysia. Asian Academy of Management Journal of Accounting and Finance, 4(1), 23-43.

Ali, S., Shahzad, S. J. H., Raza, N., \& Al-Yahyaee, K. H. (2018). Stock market efficiency: comparative analysis of Islamic and conventional stock markets. Physica A: Statistical Mechanics and Its Applications, 503(1), 139-153.

Amin, F. A. M., Yahya, S. F., Ibrahim, S. A. S., \& Kamari, M. S. M. (2018). Portfolio Risk Measurement Based on Value at Risk (VaR). AIP Conference Proceedings, 1974(1), 020012. AIP Publishing LLC.

Bouoiyour, J., Selmi, R., \& Wohar, M. E. (2018). Are Islamic stock markets efficient? A multifractal detrended fluctuation analysis. Finance Research Letters, 26(1), 100-105.

Charles, A., Darne, O., \& Pop, A. (2015). Risk and ethical investment: empirical evidence from Dow Jones Islamic indexes. Research in International Business and Finance, 35(1), 3356.

Dewandaru, G., Bacha, O. I., Masih, A. M. M., \& Masih, R. (2015), Risk-return characteristics of Islamic equity indices: multi-timescales analysis. Journal of Multinational Financial Management, 29(1), 115-138.

Dharani, M., \& Natarajan, P. (2011). Seasonal anomalies between S\&P CNX Nifty Sharīah index and S\&P CNX Nifty index in India. Journal of Social and Development Sciences, 1(3), 101-108.

Elfakhani, S., Hassan, M. K., \& Sidani, Y. (2005). Comparative performance of Islamic versus secular mutual funds. In 12th Economic Research Forum Conference in Cairo, Egypt (Vol. 53, pp. 19-21).

Girard, E. C., \& Hassan, M. K. (2008). Is there a cost to faith-based investing: evidence from FTSE Islamic indices. The Journal of Investing, 17(4), 112-121.

Hayat, R., \& Kraeussl, R. (2011). Risk and return characteristics of Islamic equity funds. Emerging Markets Review, 12(2), 189-203.

Hersugondo, H., Sadiyah, C., Handriani, E., Subagyo, H., \& Astuti, S, D. (2020). An Analysis of Sharia and Conventional Shares' System at Indonesia Stock Exchange. Perisai: Islamic Banking and Finance Journal. 4(1), 1-16.

Ho, C. S. F., Rahman, N. A. A., Yusuf, N. H. M., \& Zamzamin, Z. (2014). Performance of global Islamic versus conventional share indices: international evidence. Pacific-Basin Finance Journal, 28 (1), 110-121.

Hussein, K. (2004). Ethical investment: empirical evidence from FTSE Islamic index. Islamic Economic Studies, 12(1).

Johan, Z. J. (2018). Shariah compliant credit cards: Disputes and steps forward. Journal of Emerging Economies and Islamic Research, 6(1), 44-54.

Jawadi, F., Jawadi, N., \& Louhichi, W. (2014). Conventional and Islamic stock price performance: An empirical investigation. International Economics, 137, 73-87.

Jensen, M. C. (1968). The performance of mutual funds in the period 1945-1964. Journal of Finance, 48(1), 389-416.

Kabir, S. H., Masih, A. M. M., \& Bacha, O. I. (2017). Risk-Return Profiles of Islamic Equities and Commodity Portfolios in Different Market Conditions. Emerging Markets Finance and Trade, 53(7), 1477-1500.

Lean, H. H., \& Parsva, P. (2012). Performance of Islamic indices in Malaysia FTSE market: Empirical evidence from CAPM. Journal of Applied Sciences, 12(12), 1274-1281. 
Mansor, F., \& Bhatti, M. I. (2011). Risk and return analysis on performance of the Islamic mutual funds: evidence from Malaysia. Global Economy and Finance Journal, 4(1), 1931.

Mwamba, J.W.M., Hammoudeh, S., \& Gupta, R. (2017). Financial tail risks in conventional and Islamic stock markets: a comparative analysis. Pacific-Basin Finance Journal, 42(1), 6082.

Rakhi, S., Hoque, A., \& Hassan, K. (2018). Analysing the Performance of Malaysian Islamic and Conventional Stock Portfolios. e-Proceedings of the Global Conference on Islamic Economics and Finance.

Rizvi, S. A. R., \& Arshad, S. (2017). Understanding time-varying systematic risks in Islamic and conventional sectoral indices. Economic Modelling, 70 (1), 561-570.

Sahudin, Z., Ismail, Z., Sulaiman, S., Rahman, H., \& Jaafar, M. (2019). Capital Structure Determinants of Shariah-compliant Firms. Journal of Emerging Economies and Islamic Research, 7(1), 65-75.

Sharpe, W. F. (1966). Mutual fund performance. The Journal of Business, 39(1), 119-138.

Siddiqui, A. R. (2002). Transparency and accountability: Dow Jones Islamic market index. In International Islamic Finance Forum, Dubai (pp. 17-19).

Sukmana, R., \& Kolid, M. (2012). Impact of global financial crisis on Islamic and conventional stocks in emerging market: an application of ARCH and GARCH method. Asian Academy of Management Journal of Accounting \& Finance, 31(2), 357-370.

Tas, O., Tokmakcioglu, K., Ugurlu, U., \& Isiker, M. (2016). Comparison of ethical and conventional portfolios with second-order stochastic dominance efficiency test. International Journal of Islamic and Middle Eastern Finance and Management, 9(4), 492-511.

Treynor, J. L. (1965). How to rate management of investment fund. Harvard Business Review, 44(3), 63-75.

Wah, L. S., \& Johari, A. (2014). Risk-Adjusted Performance of Malaysian Real Estate Investment Trust Funds. Jurnal Pengurusan, 41, 3-11. 